\title{
Penggunaan Media Bungnge Tallo' untuk meningkatkan Aktivitas Belajar Siswa pada Materi Bilangan Kubik
}

\author{
Arnold Jacobus \\ Sekolah Dasar Negeri 90 Singkawang \\ E-mail: arnold.jacobus@yahoo.com
}

\begin{abstract}
Abstrak: Salah satu masalah yang dialami siswa kelas VI SD Negeri 90 Singkawang dalam pembelajaran matematika adalah kurangnya pemahaman terhadap konsepmatematika, sehingga nilaisiswa selalu rendah. Penyebabnya adalah pembelajaran yang dilakukan guru dalam menyampaikan konsep matematikatidak menyenangkan bagi siswa. Salah satu cara mengatasi masalah tersebut, guru menerapkan pembelajaran matematika dengan media pembelajaran Bungnge Tallo'APATI. Dengan media pembelajaran Bungnge Tallo' APATI pada pembelajaran bilangan kubik, siswa dapat termotivasi dalam pembelajaran, sehingga dapat meningkatkan hasil belajarnya. Penelitian dilakukan melalui penelitian tindakan kelas (PTK). Hasil penelitian menunjukkan peningkatan dari prasiklus dengan nilai rata-rata 45 meningkat 64 pada siklus I dan meningkat lagi menjadi 89 pada siklus II, dengan ketuntasan minimal $100 \%$.
\end{abstract}

Kata kunci: Matematika; Bungnge Tallo’ APATI; Hasil Belajar.

\section{PENDAHULUAN}

Sebagian besar orang memandang bahwa matematika itu adalah pelajaran yang sulit, menyeramkan, bahkan ada beberapa anak yang tidak suka sama sekali dengan matematika. Tetapi, mau tidak mau anak-anak harus mempelajarinya, karena merupakan sarana untuk memecahkan masalah seharihari, seperti halnya membaca dan menulis. Kesulitan mempelajari matematika harus diatasi sejak dini, kalau tidak akan menghadapi banyak masalah dikemudian hari.

Berbagai permasalahan yang menyebabkan kurang berhasilnya pembelajaran matematika yang dilaksanakan, dipengaruhi oleh berbagai faktor salah satunya masih banyak dijumpai proses pembelajaran matematika di sekolah dasar yang hanya menggunakan metode konvensional, yaitu ceramah dan pemberian tugas. Ada beberapa alasan yang dikemukakan, sehingga metode "kuno" ini masih dipakai hingga sekarang. Contohnya,pembelajaran matematika yang dilakukan di kelas VI SD Negeri 90 Singkawang pada materi bilangan kubikdilakukan kurang menarik minat belajar siswa, guru menyampaikan materi pelajaran dan menjelaskan cara mencari hasil dari bilangan kubik, setelah itu siswa diminta untuk mengerjakan tugas. Pembelajaran hanya berpusat pada guru (Teacher Centered Learning), sehingga siswa tidak aktif dalam mengikuti pembelajaran. Konsep matematika yang diajarkan kepada anak, tidak tertanam baik dalam diri mereka,sehingga berdampak pada hasil belajar siswa yang nilai rata-ratanya masih di bawah nilai KKM materi tersebut, yaitu sebanyak $85 \%$ siswa mendapat nilai di bawah KKM (65).
Pada hakekatnya, dalam proses pembelajaran (termasuk di dalamnya pembelajaran matematika) merupakan proses komunikasi dimana seorang guru harus dapat menyampaikan apa yang ia miliki kepada siswanya pula.Namun dalam prakteknya pada pembelajaran, proses pengkomunikasian suatu materi agar mudah diserap, dipahami, dan dihayati oleh siswa

tidaklah mudah. Pengalaman menunjukan bahwa dalam proses penyampaian materi terutama materi matematika sering terjadi hambatan atau penyimpangan, sehingga penyampaiannya menjadi tidak efektif dan efisien. Bahkan soal yang sebenarnya mudah atau sederhana tampak menjadi sulit bagi siswa.

Pendidik perlu menyadari bahwa pada umumnya siswa berpikir dari hal-hal yang bersifat konkret menuju abstrak. Untuk menjembataninya, seorang guru seyogyanya memikirkan cara-cara penyampaian yang efektif agar sesuatu yang disampaikan itu dapat diterima dengan mudah oleh siswa. Untuk pemikiran inilah maka diperlukan alat bantu lain berupa "media pembelajaran atau alat peraga".Media merupakan kata jamak dari medium yang berasal dari bahasa latin yang berarti "antara" yaitu segala sesuatu yang membawa informasi antara sumber informasi dan penerima informasi [1]. Para pengajar membutuhkan alternatif yang baru, cara-cara baru, serta konsep-konsep baru bagaimana cara mengenalkan matematika kepada siswa, tanpa memberikan kesan matematika itu menyeramkan, justru kita harus memberikan kesan matematika itu menarik, matematika itu adalah permainan, matematika itu menyenangkan.

Gambaran negatif terhadap pelajaran matematika sebenarnya dapat diminimalkan yaitu dengan penggunaan 
metode dan media yang sesuai dengan kondisi siswa. Sebagai guru kita perlu mengenal macam-macam media pembelajaran yang dapat kita gunakan dalam membantu Kegiatan Belajar Mengajar (KBM), khususnya dalam pembelajaran matematika. Contohnya dengan menggunakan media pembelajaranBungnge Tallo’ APATI (Bunga Telur Akar Pangkat Tiga).

Media merupakan kata jamak dari medium yang berasal dari bahasa latin yang berarti "antara" yaitu segala sesuatu yang membawa informasi antara sumber informasi dan penerima informasi [1]. Pernyataan tersebut dapat diartikan bahwa segala sesuatu yang dapat menjembatani informasi antara sumber informasi dan penerima informasi dapat dikatakan sebagai media.

Macam-macam media pembelajaran yaitu: 1) media audio, yaitu rekaman suara, rekaman radio, musik dan lain-lain. Media visual, antara lain, fhoto, grafik, diagram, peta, poster, papan tulis, buku dan lain-lain. 3) media audio visual, contohnya film, video, animasi, dan lain-lain.

Media pembelajaran memiliki empat fungsi, yaitu 1) fungsi atensi, yaitu menarik dan mengarahkan perhatian peserta didik untuk berkonsentrasi kepada isi pelajaran yang berkaitan dengan visual yang ditampilkan atau menyertai teks materi pelajaran. 2) fungsi afektif, adalah fungsi untuk menggugah emosi dan sikap peserta didik. 3) fungsi kognitif, adalah bertujuan untuk mengingat informasi atau pesan yang terkandung dalam gambar. 4) fungsi kompensatoris, adalah fungsi media yang memberikan konteks untuk memahami teks, membantu peserta didik yang lemah dalam membaca, mengorganisasikan informasi dalam teks dan mengingatnya kembali [2].

Pembelajaran berbasis budaya dilandaskan pada pengakuan terhadap budaya sebagai bagian yang fundamental (mendasar dan penting) bagi pendidikan, ekspresi dan komunikasi suatu gagasan, dan perkembangan pengetahuan. Budaya merupakan alat untuk memotivasi siswa dalam mengaplikasikan pengetahuan, bekerja secara kooperatif, dan mempersepsikan keterkaitan antara berbagai mata pelajaran. Siswa diberi kebebasan untuk belajar dan menggali prinsip-prinsip dalam suatu mata pelajaran untuk menemukan hal-hal yang bermakna disekelilingnya, dan mendorongnya untuk membuka dan menemukan hal-hal yang baru di dunia baru.

Pembelajaran berbasis budaya dibedakan menjadi tiga macam, yaitu: belajar tentang budaya, belajar dengan budaya, dan belajar melalui budaya[3]. Media pembelajaran yang dirancang untuk penelitian ini adalah Bungnge' Tallo' APATI (Bunga Telur Akar Pangkat Tiga). Media pembelajaran ini digunakan untuk menyampaikan konsep matematika pada materi mencari hasil dari suatu bilangan kubik (belajar dengan budaya), yang dipadukan dengan budaya lokal Melayu Sambas Propinsi Kalimantan Barat (salah satu perlengkapan dalam upacara adat perkawinan).

Penggunaan media ini dirancang dalam bentuk permainan mencari pasangan, yaitu pasangan pohon soal dengan pot jawaban. Model pembelajaran yang sesuai adalah make a match. a. Alat dan Bahan

Alat dan bahan untuk membuat Bungnge Tallo' APATI sebagai berikut :

1. Gunting

2. Lem kertas

3. Kertas warna warni

4. Kawat kecil dan besar

5. Belahan bambu kecil

6. Bola Pimpong / mainan buah-buahan.

7. Gelas plastik bekas air mineral

b. Proses Pembuatan

1. Bentuk pola bunga, dan tulis soal akar pangkat tiga suatu bilangan

2. Bentuk lagi dua buah daun untuk jawaban.

3. Untuk batang tempat melekatkan bunga dan daun dibuat darisedotan atau dari belahan bambu.

4. Kemudian siapkan gelas plastik bekas air mineral yang berisi pasiruntuk tempat jawaban dari soal bilangan kubik.

c. Penggunaan dalam Pembelajaran

1. Cara Penggunaan Media

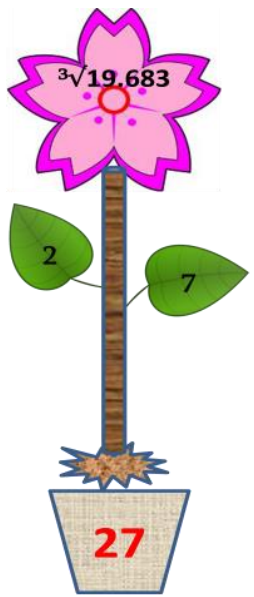
1. Langkah pertama, Setelah kita mengetahui hasil dari satuan pangkat tiga, Selanjutnya kita amati soal di bunga, lihat bilangan ribuan (sebelah kiri titik) tertulis 19, maka perhatikan tabel di kolom hasil, mana yang mendekati di bawah 19 , ternyata 8 maka satuan pangkat tiganya yg kita tulis di daun sebelah kiri yaitu angka 2.
2. Langkah kedua, lihat soal lagi. Perhatikan angka satuannya (bilangan di ujung sebelah kanan) yaitu 3. maka amati tabel lagi, mana yang dikolom hasil satuannya angka 3 , ternyata yang satuanya 3 adalah 343. maka satuan pangkat tiganya yang kita tulis di daun sebelah kanan yaitu 7.
3. Langkah ketiga, gabungkan bilangan yang ada di daun, yaitu angka 2 dan 7, menjadi 27. itulah jawabannya.

Gambar 1. Langkah Penggunaan Media APATI 
Tabel 1.

Perhitungan APATI

\begin{tabular}{cc}
\hline Satuan $^{3}$ & Hasil \\
\hline $1^{3}$ & 1 \\
$2^{3}$ & 8 \\
$3^{3}$ & 27 \\
$4^{3}$ & 64 \\
$5^{3}$ & 125 \\
$6^{3}$ & 216 \\
$7^{3}$ & 343 \\
$8^{3}$ & 512 \\
$9^{3}$ & 729 \\
\hline
\end{tabular}

2. Aplikasi Media Pembelajaran

(Model Pembelajaran: Make a Match)

Langkah-Langkah Pembelajaran

a. Siswa mendengarkan penjelasan guru tentang cara mencari hasil pangkat tiga dari bilangan satuan. $\left(2^{3}=\right.$ $2 \times 2 \times 2=8$ ) dan cara mencari akar pangkat tiga dari suatu bilangan.

b. Siswa dijelaskan cara penggunaan media dan bentuk permainannya.

c. Siswa dibagi menjadi 4 kelompok, setiap kelompok terdiri dari 4-5 orang.

d. Siswa diajak keluar kelas menuju lapangan.

e. Siswa diminta untuk meletakkan beberapa pot jawaban (gelas air mineral) di sekeliling lapangan.

f. Setiap perwakilan kelompok mengambil potonganpotongan Bungnge Tallo'APATI (1 buah bunga yang berisi soal, 2 buah daun, dan 1 buah batang dari sedotan/bambu kecil).

g. Siswa kembali kedalam kelompok untuk menyatukan bagian-bagian tadi menjadi Bungnge Tallo'APATI.

h. Siswa berdiskusi dengan temannya untuk mencari hasil akar pangkat tiga.

i. Siswa mencari pot yang berisi jawaban dari soal yang telah dikerjakan.

j. Setelah pot jawaban ditemukan, siswa kembali lagi dalam kelompoknya.

k. Giliran orang kedua dalam kelompok mengambil tanaman soal.

1. Setelah semua orang dalam kelompok selesai, siswa diajak melihat hasil pekerjaan mereka.

m. Siswa yang lain bersama guru menanggapi hasil tugas kelompok yang lain (Jawaban yang benar diberi telur mainan/bola pingpong).

n. Siswa melakukan kegiatan pameran hasil kerja kelompok mereka.

o. Siswa diberi kesempatan oleh guru untuk menanyakan hal yang belum jelas.

p. Guru menjelaskan secara detail tentang materi yang disampaikan.

Pada dasarnya, media pembelajaran ini bisa disederhanakan menjadi setangkai bunga, tanpa menambahkan unsure pengenalan budaya, yang disebut pohon APATI. Hal yang terpenting adalah mencoba menjembatani siswa untuk mengenal pemecahan masalah matematika dengan cara yang mudah menggunakan metode yang efektif dan menyenangkan.

\section{METODE}

Metode dalam penelitian ini adalah PTK (Penelitian Tindakan Kelas), yang merupakan bentuk kajian sistematis reflektif oleh pelaku tindakan yang dilakukan untuk meningkatkan kemantapan rasional dari tindakan mereka dalam melaksanakan tugas, memperdalam pemahaman terhadap tindakan-tindakan yang dilakukannya itu, serta memperbaiki kondisi pembelajaranPenelitian dilaksanakan dengan menggunakan empat tahap kegiatan, yaitu merencanakan, melakukan tindakan, pengamatan (pengolahan data), dan refleksi [4].

Karakteristik siswa kelas VI SD Negeri 90 Singkawang adalah sebagai berikut: Jumlah siswa laki-laki sebanyak 7 orang dan jumlah siswa perempuan adalah 14 orang yang berasal dari kelurahanSetapuk Besar. Latar belakang siswa berasal dari keluarga dengan tingkat ekonomi menengah ke bawah. $70 \%$ pekerjaan orang tua siswa adalah petani , $10 \%$ adalah pedagang, sisanya buruh dan Pegawai Negeri Sipil.

\section{Siklus I}

\section{HASIL DAN PEMBAHASAN}

Pada tahap pelaksanaan ini berpedoman pada apa yang telah direncanakan peneliti bersama teman sejawat sebagai upaya peningkatan hasil belajar siswa. Pada tahap ini peneliti melaksanakan pembelajaran sesuai dengan skenario pembelajaran yang telah disusun yaitu menerapkan metode permainan “Bungnge Tallo' akar pangkat tiga”.

Adapun prosedur perbaikan yang diterapkan dalam hal ini antara lain:

a. Perencanaan (Planing) :

1. Guru mempersiapkan materi pembelajaran.

2. Guru memeriksa kembali urutan kegiatan yang akan dilakukan dalam proses pembelajaran, dari kegiatan awal sampai kegiatan akhir.

3. Guru menyiapakan media permainan yang akan digunakan

4. Guru mengecek lembar observasi yang telah dibuat

Pada tahap siklus I ini guru berusaha menghadirkan media permainan yang dibuat dari kertas yang disebut Pohon APATI (Pohon Akar Pangkat Tiga).

Setelah media pembelajaran selesai dibuat, maka peneliti bersama teman-teman guru melakukan uji coba media pembelajaran. Ini dilakukan untuk mengetahui apakah media pembelajaran mudah digunakan oleh siswa, dan dapat dipahami cara penggunaannya pada saat pembelajaran nanti. Proses ini juga dilakukan untuk mencoba validitas instrumen penilaian yang telah dibuat.

b. Tindakan Perbaikan (Action)

1. Mengajukan pertanyaan tentang materi sebelumnya sebagai kegiatan awal

2. Memberikan motivasi kepada siswa tentang manfaat mempelajari materi pelajaran yang akan disampaikan 
3. Membahas materi pelajaran dengan menggunakan media permainan yang telah dibuat

4. Pemberian tugas kelompok

5. Menyimpulkan materi pelajaran

6. Memberikan tes evaluasi sebagai tindak lanjut

\section{c. Pengamatan danPengumpulan Data (Observation)}

Selama pembelajaran guru dan teman sejawat melakukan pengamatan aktivitas siswa dengan bantuan lembar observasi dan penilaian hasil belajar. Berdasarkan hasil observasi dan penilaian, didapat data siswa (tabel 2).

Dari hasil penelitian siklus I dapat dilihat peningkatan hasil belajar siswa dibandingkan dengan prasiklus sebelumnya dengan nilai rata-rata 45 menjadi 64, dengan persentase ketuntasan minimal sebesar $67 \%$ siswa. Dari hasil siklus I, siswa memiliki antusias dalam mengikuti pembelajaran, rasa ingin tahu siswa meningkat. Sedangkan hal-hal yang belum dicapai dalam siklus I adalah hasil belajar siswa belum memuaskan karena media yang digunakan hanya satu buahpohon akar pangkat tiga tiap kelompok, sehingga tidak semua anak dapat menggunakannya. Oleh karena itu, peneliti akan memperbaiki kekurangan yang terjadi pada Siklus I.

\section{d. Refleksi diri}

Dari data yang telah dikumpulkan, maka peneliti bersama supervisor dan teman sejawat menyimpulkan bahwa:

1. Hanya 14 orang siswa yang mendapatkan nilai di atas KKM (67\% siswa)

2. Siswa yang mendapat nilai minimal 65 adalah siswa yang memang pintar.

Berdasarkan hasil temuan itu, ternyata perbaikan pembelajaran belum mencapi tujuan yang diinginkan, maka peneliti akan melakukan perbaikan pembelajaran siklus II.

Siklus II

Pada tahap pelaksanaan siklus II ini berpedoman dan mengacu pada hasil penelitian siklus I, yaitu :

a. Perencanaan (Planing)

1. Mempersiapkan materi pelajaran

2. Memeriksa kembali media permainan yang akan digunakan guru dan siswa

3. Mengecek urutan kegiatan yang akan dilakukan dalam prosespembelajaran, mulai dari kegiatan awal sampai kegiatan akhir

4. Mengecek lembar tes formatif.

5. Mengecek kembali lembar observasi yang sudah dibuat bersama supervisor dan teman sejawat.

b.Tindakan Perbaikan (Action)

1. Mengajukan pertanyaan tentang materi sebelumnya sebagai kegiatan awal.

2. Memberikan motivasi kepada siswa tentang manfaat mempelajari materi pelajaran yang akan disampaikan.

3. Membahas materi pelajaran.

4. Membagi siswa menjadi beberapa kelompok

5. Memberikan media tanaman akar pangkat tiga pada tiap anggota kelompok
6. Siswa diminta menyelesaikan tugas yang telah diberikan dengan menggunakan media permainan.

7. Siswa presentasi hasil tugas kelompok di depan kelas.

8. Memberikan tes evaluasi kepada siswa.

Kegiatan awalguru mengondisikan siswa agar siap untuk menerima pelajaran, setelah itu siswa ditanya tentangmateri bilangan pangkat dua dan pangkat tiga. Ini dilakukan untuk menyadarkan siswa bahwa materi yang akan dibahas berhubungan dengan pengetahuan yang telah dikuasainya. Banyak siswa yang menjawab pertanyaan dari guru, disini guru sudah menarik siswa untuk masuk ke dalam dunia pembelajaran yang akan guru ciptakan, dan juga diharapkan siswa dapat mengaitkan pengetahuannya tentang bilangan pangkat dua dan pangkat tiga dengan konsep matematika bilangan kubik yang akan mereka terima dalam pembelajaran ini. Pembelajaran bermakna juga akan guru ciptakan dengan mengaitkan pengetahuan mereka tentang bilangan pangkat dua dan pangkat tigadengan konsep matematika bilangan kubik yang akan mereka peroleh dalam proses pembelajaran nanti. Pertanyaan awal yang guru berikan adalah "anak-anak apakah kalian tahu hasil dari $2^{3}, 4^{3}, 5^{3}, 8^{3}$ ?" siswa banyak yang menjawab pertanyaan guru. Namun ketika guru bertanya tentang hasil dari bilangan kubik yaitu,ának-anak apakah kalian tahu hasil dari $\sqrt[3]{\mathbf{5 . 8 3 2}}$ ? maka siswa banyak yang terdiam tidak bisa menjawab, ada yang mencoret-coret kertas sampai 5 menit kemudian baru bisa menjawab. Ketika guru bertanya dengan cara apa mereka mencari jawabannya, maka mereka mengatakan dengan cara menebak bilangan yang dikalikan tiga kali. Mereka mencoba dengan bilangan 15 x 15 x 15 , jika jawabannya belum sesuai dengan soal, maka siswa mencoba dengan $16 \times 16 \times 16$, dan seterusnya sampai jawabannya sesuai dengan soal.

Setelah siswa diajak bernyanyi lagu “Kebunku” yang sesuai dengan pembelajaran yang akan dilakukan, guru menyampaikan tujuan pembelajaran, bahwa setelah siswa mengikuti pembelajaran, maka diharapkan siswa dapat menentukan hasil dari bilangan kubik dengan mudah.

Kegiatan inti guru menjelaskan bentuk kegiatanpembelajaran dengan menggunakan tanaman akar pangkat tiga. Terlebih dahulu siswa dijelaskan bagaimana cara mencari hasil dari bilangan kubik.Cara menyelesaikan hasil dari akar pangkat yaitu : contoh soal " $\sqrt{ } \underline{\mathbf{5}} .83 \underline{2}$ ?" siswa terlebih dahulu diminta untuk mengetahui hasil dari satuan pangkat tiga $\mathbf{1}^{3}-\mathbf{1 0}^{3}$.

Soal “ ${ }^{3} \sqrt{\mathbf{5}} .83 \underline{\mathbf{2}}$, terlebih dahulu dilihat bilangan ribuan pada soal yaitu 5, maka lihat tabel hasil satuan pangkat tiga, mana yang hasilnya mendekati dibawah 5 , ternyata hasilnya yang mendekati 5 adalah $1^{3}=1$ maka kita tulis pada daun sebelah kiri angka 1. Langkah selanjutnya lihat bilangan satuan pada soal yaitu angka 2, kita lihat lagi hasil dari satuan pangkat tiga, mana yang hasil satuannya 2 , ternyata $8^{3}=512$ yang satuannya 2 maka pada daun yang sebelah kiri kita tulis 8 . Kemudian kedua angka yang ada pada daun kita gabungkan menjadi 18, dan kita cari pot jawaban yang tertulis 18 karena itu adalah jawaban dari ${ }^{\prime 3} \sqrt{5} 5.832=18$ 
Setelah penjelasan cara pengerjaan, siswa membentuk kelompok yang terdiri dari 4-5 orang, kemudian tiap anggota kelompok mendapatkan satu buah tanaman akar pangkat tiga yang telah berisi soal bilangan kubik. Pada tahap ini, siswa terlebih dahulu diminta untuk mengambil di meja guru bagianbagian dari media permainan tanaman akar pangkat tiga yang masih terpisah-pisah, yaitu bagian bunga yang berisi soal, 2 buah daun, dan batang yang terbuat dari sedotan. Kemudian siswa kembali ke meja kelompok untuk merangkai tanaman akar pangkat tiga. Terlihat siswa aktif berdiskusi dengan teman dalam kelompoknya. Ada siswa yang asyik merangkai media, dan siswa yang lain mencari hasil dari bilangan kubik yang ada pada daun.Banyak siswa sangat senang dalam tugas kelompok, Suasana kelas yang tadinya terlihat hening dikarenakan kehadiran para guru pengamat, menjadi cair dan menyenangkan dengan adanya pembelajaran metode permainan. Siswa berlomba-lomba mencari pot jawaban yang telah guru letakkan di sekeliling kelas. Guru juga aktif membimbing siswa yang kelihatan bingung untuk mengerjakan tugas kelompok. Setelah tugas kelompok diselesaikan maka guru meminta siswa untuk melaporkan hasil pekerjaan kelompoknya di depan kelas. Setiap kelompok mendapat tugas presentasi masing-masing satu soal. Kelompok yang lain menanggapi hasil pekerjaan kelompok yang melakukan presentasi. Pada saat presentasi semua kelompok telah selesai, maka siswa dengan bantuan guru menyimpulkan materi pelajaran yang telah diterima. Setelah presentasi, hasil tugas siswa di pajang di depan kelas agar siswa semakin termotivasi dalam mengikuti pembelajaran.

Kegiatan penutup siswa diberi tes akhir selama 10 menit, terlihat siswa serius dan percaya diri dalam mengerjakan tugas tersebut. Setelah itu, guru menutup pembelajaran dengan menginformasikan materi yang akan dipelajari pada pertemuan berikutnya dan apa yang harus dikerjakan siswa di rumah. Dari hasil tugas akhir didapat rata-rata nilai siswa adalah 84 ini menunjukkan bahwa siswa sudah melampaui target KKM dari Indikator materi pelajaran yang telah selesai diajarkan tersebut (65).

c. Pengamatan dan Pengumpulan Data (Observation)

Berdasarkan hasil observasi, didapat data siswa sebagai berikut.

Tabel 2.

Lembar Observasi Aktivitas Siswa

\begin{tabular}{lcccc}
\hline & \multicolumn{5}{c}{ Jumlah } \\
\hline \multirow{2}{*}{ Aspek Yang Diamati } & \multicolumn{2}{c}{ Siklus I } & \multicolumn{2}{c}{ Siklus II } \\
\cline { 2 - 5 } Siswa & 12 & 57 & 17 & 80 \\
\hline 1. Siswa memperhatikan & 14 & 67 & 19 & 90 \\
2. Siswa terlibat aktif & 10 & 47 & 17 & 80 \\
3. Siswa memberikan & 14 & 67 & 20 & 95 \\
$\quad$ tanggapan & 15 & 71 & 20 & 95 \\
4. Siswa termotivasi & 17 & 80 & 19 & 90 \\
5. Siswa merasa senang dan & 17 & 80 & 20 & 95 \\
$\quad$ ceria & & & &
\end{tabular}

8. Siswa berani mencoba

9. Siswa merasa terbimbing dan termotivasi

10. Siswa senang menerima tugas tindak lanjut

Adapun hasil dari penelitian siklus II ini sudah memuaskan karena semua siswa berperan aktif dalam pembelajaran, siswa dapat mengerjakan soal dengan baik, sehingga hasil belajar siswa meningkat. Hasil belajar siswa pada siklus II dapat dilihat padaTabel 3 .

Tabel 3. Hasil Belajar Siswa

\begin{tabular}{|c|c|c|c|c|c|}
\hline No. & $\begin{array}{l}\text { Nama } \\
\text { Siswa }\end{array}$ & $\begin{array}{c}\text { Pra } \\
\text { Siklus } \\
\end{array}$ & Siklus I & $\begin{array}{c}\text { Siklus } \\
\text { II }\end{array}$ & Ket. \\
\hline 1 & $\mathrm{AM}$ & 65 & 75 & 90 & Tuntas \\
\hline 2 & $\mathrm{AN}$ & 25 & 35 & 60 & Tuntas \\
\hline 3 & AR & 50 & 75 & 80 & Tuntas \\
\hline 4 & CR & 50 & 70 & 90 & Tuntas \\
\hline 5 & DF & 55 & 60 & 85 & Tuntas \\
\hline 6 & DS & 55 & 70 & 85 & Tuntas \\
\hline 7 & DP & 35 & 40 & 90 & Tuntas \\
\hline 8 & HW & 25 & 40 & 85 & Tuntas \\
\hline 9 & IF & 50 & 60 & 90 & Tuntas \\
\hline 10 & $\mathrm{LT}$ & 30 & 65 & 90 & Tuntas \\
\hline 11 & NL & 55 & 75 & 85 & Tuntas \\
\hline 12 & NR & 35 & 55 & 60 & Tuntas \\
\hline 13 & NS & 35 & 75 & 85 & Tuntas \\
\hline 14 & NM & 45 & 50 & 95 & Tuntas \\
\hline 15 & $\mathrm{RB}$ & 40 & 75 & 85 & Tuntas \\
\hline 16 & RN & 25 & 50 & 85 & Tuntas \\
\hline 17 & SY & 30 & 45 & 95 & Tuntas \\
\hline 18 & SR & 70 & 80 & 90 & Tuntas \\
\hline 19 & $\mathrm{TN}$ & 50 & 60 & 90 & Tuntas \\
\hline 20 & ZR & 35 & 65 & 95 & Tuntas \\
\hline 21 & $\mathrm{HM}$ & 40 & 60 & 80 & Tuntas \\
\hline \multicolumn{2}{|c|}{ Jumlah } & 925 & 1340 & 1850 & \multirow{2}{*}{$\begin{array}{l}\text { Ketuntas } \\
\text { an } 100 \%\end{array}$} \\
\hline \multicolumn{2}{|c|}{ Rata-Rata } & 42 & 61 & 84 & \\
\hline
\end{tabular}

\section{d. Refleksi diri}

Dari data yang telah dikumpulkan, maka peneliti bersama supervisor dan teman sejawat menyimpulkan bahwa:

1. Semua siswa mencapai nilai ketuntasan minimal (100\%).

2. Hasil belajar siswa dapat dikatakan cukup memuaskan.

3. Media pembelajaran dapat meningkatkan minat belajar siswa sehingga siswa senang mengikuti pembelajaran. Itu sangat berpengaruh terhadap perolehan nilai siswa.

Berdasarkan nilai yang diperoleh oleh siswa, dan ternyata telah mencapai tujuan perbaikan pembelajaran. Maka, penulis bersama supervisor dan teman sejawat berpendapat bahwa perbaikan pembelajaran bisa dikatakan berhasil.

Hasil belajar siswa dimulai dari prasiklus, siklus I sampai siklus II sangat terlihat adanya perbedaan yaitu adanya peningkatan nilai rata-rata hasil belajar yaitu prasiklus rata-rata 45, kemudian siklus I rata-rata 64 dan pada siklus II rata-rata 89. Persentase ketuntasan minimal pada siklus I sebesar $67 \%$ siswa meningkat menjadi $100 \%$ pada siklus II. Dengan demikian, dapat dikatakan bahwa dengan menggunakan media 
pembelajaran dalam proses pembelajaran, dapat meningkatkan aktivitas belajar siswa, yang berdampak pada peningkatan hasil belajar siswa kelas VI di SD Negeri 90 Singkawang.

Penelitian ini didukung oleh pendapat [5 ] sebagai berikut:

a. Media pembelajaaran berfungsi efektif dalam memotivasi belajar siswa.

b. Terdapat perbandingan keberhasilan 6:1 antara pengajaran yang menggunakan media pembelajaran dengan yang tidak menggunakannya.

c. Memanipulasi (mengutak-atik) media pembelajaraan sangat penting bagi siswa.

d. Gambar dari benda, sebagai media pembelajaran dalam pengajaran, memiliki kegunaan yang tidak jauh berbeda dengan bendanya sendiri.

Penggunaan media pembelajaran harus dilaksanakan secara cermat. Jangan sampai konsep menjadi lebih rumit akibat diuraikan dengan bantuan media pembelajaran. Media pembelajaran harus digunakan secara tepat, disesuaikan dengan sifat materi yang disampaikan, metode pengajaran yang digunakan dan tahap perkembangan mental anak.

Penggunaan media pembelajaran harus mampu menghasilkan generalisasi atau kesimpulan abstrak ke representasi konkret. Maksudnya, dengan bantuan media pembelajaran yang sifatnya konkret, siswa diharapkan dapat menarik kesimpulan. Media pembelajaran yang digunakan tanpa persiapan bisa mengakibatkan habisnya waktu dan sedikitnya materi yang disampaikan. Media pembelajaran harus dibuat sebaik mungkin, menarik untuk diamati, dan mendorong siswa untuk bersifat penasaran (curious), sehingga diharapkan motivasi belajarnya semakin meningkat. media pembelajaran juga diharapkan menumbuhkan daya imajinasi dalam diri siswa.

Menurut penelitian sebelumnya tentang tahapan pembelajaran matematika yang dikemukakan pada referensi [6], yaitu: Tahap enaktif (konkret), Tahap iconik (semi konkret), dan Tahap simbolik (abstrak). Maka, disini penulis mencoba melaksanakan pembelajaran yang sesuai dengan tahapan yang telah dikemukakan melalui penelitian Bruner tersebut. Menurut Bruner tahapan pembelajaran matematika adalah sebagai berikut:

a. Tahap Enaktif, tahap pertama anak belajar konsep adalah berhubungan dengan benda-benda real atau mengalami peristiwa di dunia sekitarnya.

b. Tahap Ikonik, pada tahap ini, anak telah mengubah, menandai, dan menyimpan peristiwa atau benda dalam bentuk bayangan mental. Benda asli sudah digantikan dengan gambar. c. Tahap Simbolik, pada tahap terakhir ini anak dapat mengutarakan bayangan mental tersebut dalam bentuk simbol dan bahasa. Apabila ia berjumpa dengan suatu simbol, maka bayangan mental yang ditandai oleh simbol itu akan dapat dikenalnya kembali.

\section{KESIMPULAN DAN SARAN}

Penggunaan media pembelajaran oleh guru dapat menuntun siswa untuk membangun pengetahuannya sendiri. Karena siswa SD belum bisa berpikir secara abstrak, namun masih berpikir konkret, maka segala sesuatu yang dipelajarinya harus diusahakan dalam bentuk nyata. Penanaman konsep matematika harus dibuktikan dengan hal yang konkret terlebih dahulu.

Guru diharapkan mampu menciptakan pembelajaran matematika yang bermakna dan menyenangkan. Oleh sebab itu, selain guru menggunakan metode atau model pembelajaran yang beragam juga senantiasa memanfaatkan media pembelajaran. Media pembelajaran bungnge tallo' APATI yang dihadirkan dalam proses pembelajaran, dapat membuat suasana menjadi sangat menyenangkan, karena mediapembelajaran dalam matematika bisa mengalihkan pikiran siswa yang mulanya tertanam bahwa matematika itu adalah pelajaran yang membosankan, menjadi pelajaran yang mengasyikkan karena ada unsur bermainnya. Hadirnya mediapembelajaran pada proses pembelajaran matematika, dapat merubah pandangan buruk siswa terhadap pelajaran matematika, dari yang semula membosankan, menyeramkan, membingungkan, dapat menjadi pelajaran yang sangat menyenangkan dan mengasyikkan, sehingga pembelajaran bermakna yang kita harapkan bersama dapat terwujud.

\section{DAFTAR RUJUKAN}

[1] Smaldino, Lowther, \& Russell,. 2014. Instructional Technology and Media for Media Learning (Terjemahan Arif Rahman). New York: Pearson Education

[2] Azhar Arsyad. 2016. Media Pembelajaran. Jakarta: Rajagrafindo Persada.

[3] Suprayekti, dkk. 2008. Pembaharuan Pembelajaran di SD. Jakarta: Universitas Terbuka

[4] IGAK Wardhani \& Kuswaya Wihardit. 2010. Penelitian Tindakan Kelas. Jakarta: Universitas Terbuka

[5] Purwoto. 2003. Strategi Pembelajaran Matematika. Surakarta: Sebelas Maret University Press

[6 ] Dahar RW. 2011. Teori-Teori Belajar \& Pembelajaran . Jakarta: Penerbit Erlangga. 